\title{
Interrogating 'Shakespop': The Politics of Tasteful Pop Culture
}

\author{
Laboni Bhattacharya \\ Department of English, Hindu College, University of Delhi. ORCID id orcid.org/oooo-oooz- \\ 9758-3235. Email: laboni.bhattacharya@gmail.com
}

Received February 24, 2017; Revised April 14, 2017; Accepted April 30, 2017; Published May 7, 2017.

\begin{abstract}
This paper will explore the phenomenon of Shakespop, or pop-cultural referentiality to Shakespeare's work (Lanier, 2002) as a category that seemingly unites Shakespeare's authorial legacy and high cultural values with popular forms like TV, comics, YouTube videos, etc in a transgressive manner. Some examples I analyse are the Sassy Gay Friend Youtube series, Shakespeare breath mints and Neil Gaiman's Sandman comics (1989 - ). I examine them as cultural objects that deploy the dynamic tension between good taste and bad, the erudite and the base. Is the vigorous appropriation and parodic inversion of Shakespeare in popular culture a genuine deconstruction of his cultural significance? A celebratory attitude would argue that postmodernity has freed Shakespeare from his high-cultural moorings. Taking up Jostein Gripsrud's theorization of 'double-access', I would argue that postmodern proliferation of Shakespop is not an inherently democratizing phenomenon, but one that conceals its origins in access, material privilege and power.
\end{abstract}

Keywords: cultural studies, popular culture, Shakespeare, double access, class privilege, cultural capital.

\section{Introduction}

This paper engages with Shakespeare in popular culture - as collectibles, clothes, YouTube spoof videos, comic books and so on - through cultural studies, as well as Pierre Bourdieu's interrogation of the category of taste (1996) as a reification of the class divide. Since culture, while belonging to the superstructure, nevertheless gains materiality through the everyday practices of people and their lived experience (Althusser, 1971; Williams, 1980) it is significant that several attempts have been made to bring Shakespeare out of the ivory tower of academia and highbrow culture to the masses. In this context, one goes beyond comprehensive methods of historicising Shakespeare (see Greenblatt, 1980 and Sinfield, 1985) to Shakespeare in the present - in the form of, memes, T-shirts, or contestations over Shakespeare's seriousness on social media websites. Yet, when Shakespeare is democratised, does any fundamental shift occur in the material reality of

(c) AesthetixMS 2016. This Open Access article is published under a Creative Commons Attribution Non-Commercial 4.0 International License (http://creativecommons.org/licenses/by-nc/4.o/), which permits non-commercial re-use, distribution, and reproduction in any medium, provided the original work is properly cited. For citation use the DOI. For commercial re-use, please contact editor@rupkatha.com. 
class stratification on the basis of signifiers like taste and good breeding? Or are these categories preserved through a sleight of hand, as Jostein Gripsrud argues?

His theorisation of 'double-access' (1989) can be used to problematize the celebratory attitude towards 'Shakespop' (Lanier, 2002) by pointing out that certain cultural products show off their consumer's cultural fluency with the codes of both high culture and popular culture while erasing the years of training and education required for "the accumulation of high cultural capital" (Gripsrud, 1989, p. 198). I would argue that postmodern proliferation of Shakespop is not an inherently democratizing phenomenon, but one that conceals its origins in access, privilege and power. Not only does it conceal these origins, it successfully creates a system of signification whereby those who enjoy popular derivations of Shakespeare are coded as being doubly accomplished, which ironically consolidates rather than deconstructs Shakespeare's cultural authority.

The contention is not that crossovers between the realms of high and popular culture are invalid or insincere; the boundary between the two is highly permeable depending on history, geography and economic structure. Yet even if these spaces are less discrete than Adorno might have imagined them to be, it is still disingenuous to insist that postmodernist assertions about the meaninglessness of such categories actually affect the complex socio-political hierarchy arising out of the high culture/popular culture dynamic. In other words, though these categories may not be absolute in the $21^{\text {st }}$ century, the simultaneous familiarity with both highbrow and lowbrow cultural registers empowers individuals with double access. Indeed as Grisprud states, a 'total dismissal of the distinction between high and low culture may serve as an ideological veiling of the social positions of researchers and other academic intellectuals, hindering a recognition of the political limitations, obligations, and possibilities inherent in these positions' (p. 195).

\section{Re-Creating Shakespeare as 'Shakespeare-Chic'}

When speaking of Shakespeare in popular culture the concept can, as Douglas Lanier (2002) exhibits, be interpreted in a variety of ways. Firstly, the phrase 'Shakespeare-AND-popular culture' implies notions of separateness that are being radically transgressed by joining the high(brow) and the low(brow). That they can only be joined with a conjunction implies that they are two discrete entities which are neither interchangeable nor congruous. This hyphenated phrase indicates a special dispensation -Shakespeare's cultural significance has been consolidated in institutions of higher learning, scholarship and criticism, to the extent that he has become 'the Coca-Cola of canonical literature' (Lanier, 2007), a process that is nearly irreversible (Levine, 1984) - which is what furthers the assumption that Shakespeare very decidedly never was and shall be considered popular or populist.

Secondly, an important observation Elizabeth Abele makes is that "not all popular incarnations of Shakespeare are popularizing" (2004). She says that the BBC's Shakespeare productions were boring and unengaging to her as a child, even though she was habituated to watching Shakespeare adaptation on TV or in cinema that were "fun". These former adaptations maintained Shakespeare's status as a cultural icon even in a popular medium, emphasizing an aesthetic seriousness that cannot be maligned by television. The third interpretation of 'Shakespeare and popular culture' is as an instance of appropriation, as a mode of ownership, piggybacking upon the authority of the original to elevate its derivative. For example, adapting or

re-telling Shakespeare gives a boost in credibility to everything from drama societies in schools to Hollywood productions like Lawrence Olivier's Henry $V$, as Lanier himself points out. Popular 
adaptations like the film She's the Man (2006), based on Twelfth Night make Shakespeare accessible, but also escapes generic classification as just a teen film by successfully arrogating to itself Shakespeare's own cultural capital.

Finally, Douglas Lanier chooses the phrase 'Shakespop' (2002) to overcome the limitations of the hyphenated Shakespeare-and-popular-culture as well as to underscore the unity of the concept and indicate a distinct field of cultural politics. However, as is the case with all theorisations of emergent practices in the present (Williams, 1980) it can only be provisional, loosely defined against indices that are constantly shifting. It still remains debatable whether Shakespop is irrelevant in a postmodern age where an erstwhile cultural icon like Shakespeare becomes depleted of meaning, leaving it open to creative use and freeplay, or whether, more tellingly, residual notions of value allow 'popular' forms of Shakespeare to manipulate Shakespeare's cultural status to maintain brand differentiation.

In 'Shakespeare ${ }^{\mathrm{TM}}$ : Myth and Biographical Fiction' he discusses the configurations of the latter with respect to ironic or 'self-productively parodic' Shakespeare chic, such as Shakespeare bobbleheads and beanie babies (2007). Lanier points out that any interaction between a popular Shakespeare and a canonical Shakespeare is 'an interplay (emphasis mine) between two cultural systems - high and pop culture-that operate in parallel realms, two bodies of reference, sets of cultural institutions, canons of aesthetic standards, modes of constructing cultural authority' (2002). Who benefits from this interaction? Is it the category of the popular, playing with respectability politics of a literary nature to make itself more dignified? Or does this only reinforce the Shakespearean cultural index as inherently valuable? Clearly, appropriation does not significantly subvert the cultural capital of Shakespeare. Self-congratulatory consumerist products such as collectibles, posters and mugs operate in a discourse that relies upon both an insider's knowledge of a heavily mediated sign like Shakespeare, as well as a postmodern desire to relinquish any claim to a grand narrative of artistic value. On the surface, they seem to parody this icon of high culture, but what is happening is a process of re-interpretation of the texts of high culture in a new context, rather than any genuine criticism.

It is important to bear in mind that all pop culture incarnations of Shakespeare reliant upon familiarity with the canon also allow their producers and consumers access to the registers of both academic vocabulary as well as ironic distance from it, thereby making that familiarity itself look effortless and 'cool', concealing the material privileges that enable this kind of position. This variety of self-deprecating, effortless intellectuality is perfectly embodied in a product like Shakespearemints.

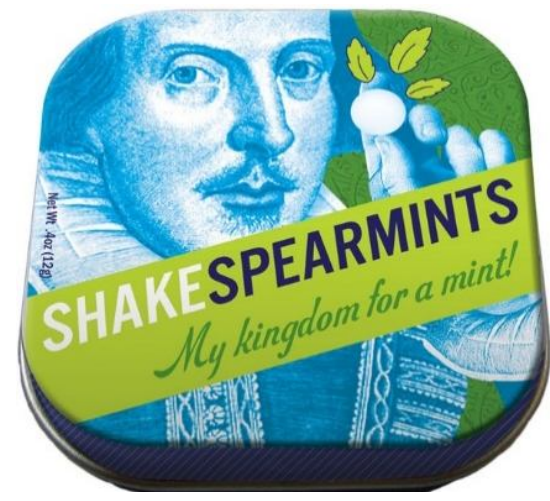

Figure 1: 'Shakespearemints' sold on The Unemployed Philosophers Guild; priced \$3 
The breath mints are marketed with a lively faux-Shakespearean spiel that gleefully references Romeo and Juliet.

"How art thou out of breath when thou hast breath? /To say to me that thou art out of breath?" Speaking of thy breath... how is thy breath? Thou will not have to wait with bated breath and whisp'ring humbleness to speak to thy knave or mistress if thou hast Shakespearemints about thy person. (The Unemployed Philosopher's Guild, 2015)

While undoubtedly amusing, the breath mints are not merely functional. They are symbolic. The mints are not only for consumption, but for being displayed like a famous brand logo, signifying the owner's intellectual credibility and proximity with Shakespeare in a manner that is relaxed, casual and "cool". Therefore, the commodity is not the breath mint, but cultural capital itself; in fact, this cultural capital is meant to be worn lightly, underplaying the strenuous efforts at acquiring this capital. Hence, choice of the breath mint rather than a framed portrait of Shakespeare becomes the perfect self-deprecatory space for this display. The website also sells Shakespeare finger-puppets.

Culture, and 'high culture' - of which Shakespeare is a part - is a bundle of practices that confers power upon those who possess it. Moreover, this particular discourse is inextricable from the concept of taste, as demonstrated by Lanier (2002, 2007) and Grande (2010). 'Taste', as Bourdieu writes, is not a 'supreme manifestation' of intellect, but an expression of a lifetime of education, exposure and class. It is a social condition that is meant to convey status, although this causal connection is consistently erased to maintain class differentiation, thereby naturalizing the belief that those from the upper classes have good taste and those from the lower classes do not. This process works to synergize higher valuation of both normative tastes as well as ideal cultural products - those who have taste use it to distinguish themselves from others.

Consider, for instance, the Guardian headline - "Leonard Cohen is John Donne to Bob Dylan's Shakespeare" - written twelve days after Cohen's death even as his contemporary went on to win a Nobel Prize. The writer muses,

[...] while Dylan's lyrical gift is wild, copious, and immoderate, Cohen's is precise, supplicatory and cloistral. Where Dylan rambunctiously inhabits the multifarious world, Cohen more often circles the many mortal contrarieties that lie between the lovers' bed and the altar - regularly, for him, the same thing. Where Dylan's genius often has a dizzying and effortless quality, Cohen's feels mesmerizingly measured. (Docx, 2016, n.p)

Anyone who wishes to engage with this editorial must be familiar with Cohen and Dylan's discography as well as Donne and Shakespeare studies. Even among the Guardians subscribers, this is a small subset. More significantly, such a comparison surreptitiously validates the fan of Dylan/Cohen and Donne/Shakespeare by signaling their good taste in music and literature. It elevates Dylan and Cohen from the realm of popular American music by comparison to icons of high literariness, affirming that they are superior to other popular musicians. Simultaneously, the cultural currency of Donne and Shakespeare is circulated and renewed in the popular realm, reminding us that they are still standards to aspire to.

The reciprocal relationship between culture as artefact and attribute ("to be cultured") reveals the way that Shakespeare functions as a transferrable commodity that is a space where class aspirations can be projected, debated, contested, asserted or affirmed. The distinctions between the two have significantly blur, as demonstrated by the existence of Shakespearemints, for instance, but they have not been erased. It is arguable that this nebulous category of 'selfproductively parodic' (Lanier 2007) products reinforces sociocultural distinctions. 
Even as materialist criticism abandons the approach of idealist literary criticism (concerned with isolating the essential meaning and unity of Shakespeare's world) and deconstructs long-held assumptions about canonicity (see Dollimore and Sinfield, 1985), one cannot conclude that there are no causative links between residual notions of cultural value and class consciousness. Shakespeare's association with good taste/breeding and social status persists despite many attempts to challenge it. Shakespeare is not merely the writer of texts, but he is the originator of a set of values, ideas and associations. Shakespeare is then a description of an effect, rather than simply a name. (Foucault, 1969) The designation 'Shakespeare' forms the limits of a certain cultural discourse. All popular culture permutations must perforce engage in a dialogue with his authorial authority, no matter how irreverent or parodic.

Even while acknowledging the durability of Shakespeare's brand value, there have been instances of genuine parody, where no cultural values are recuperated or reinterpreted. Some of this may be attributed to postcolonial response. Lawrence Levine's study of Shakespeare in the United States, where literary studies were responding to the pressure of conforming to British tastes and standards, charts the institutionalization and subsequent appropriations of Shakespeare in contemporary America and finds that the ebb and flow of Shakespeare's status has stemmed mainly from a rebellion against his heavy cultural legacy (1984). In such a framework, much of the compelling force of Shakespearian popular culture products derives from the excitement of iconoclasm or parody rather than borrowing an icon of high culture to legitimize the popular.

This holds true, for instance, in the case of 'Sassy Gay Friend', a YouTube series of sketches by Brian Gallivan that introduce the incongruous yet recognizable modern figure of the Sassy Gay friend in scenarios involving tragic Shakespeare heroines. 'This wouldn't have happened, had

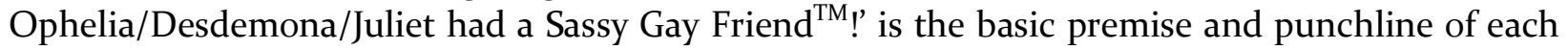
episode. Shakespearean tragedy is averted by the bubbly, assertive intervention of thee sassy gay friend, dressed in something that visually identifies him as a stock character from the Hollywood rom-com genre where the gay best friend is a comedic foil to the female protagonist, providing her with fashion advice and insulting but well-intentioned mentorship. 'You're a stupid bitch', the Sassy Gay Friend tells Ophelia, having just saved her from the brink of death. He looks into a camera and tells the viewer too, for good measure, 'She's a stupid bitch'. (Gallivan, 2010)

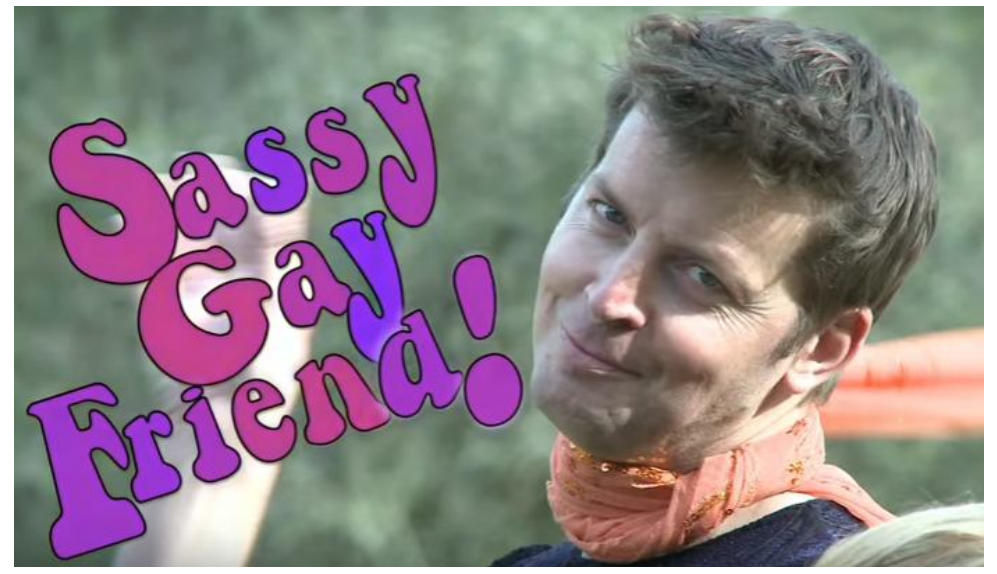

Figure 2. Brian Gallivan in "Sassy Gay Friend - HAMLET"

TvTropes.com, an online repository of narrative devices in popular media describes the function of the Sassy Gay Friend as 'the pet homosexual' who steps in when the heterosexual protagonist is about to make a bad decision by providing critical commentary unavailable to those 
embedded in heteronormativity. Despite this plot device being extremely homophobic and dehumanizing, the Sassy Gay Friend performs much the same function as the Fool in Shakespeare's plays by being the voice of reason, satire and transgressive humour as well as a companion.

Here, the device is adapted to a new context by applying it to tragic female characters like Desdemona, Juliet or Ophelia. The sassiness of his intervention upsets the plot and changes the narrative as Shakespeare's tragic heroines are saved in pop culture revisionism by a treat-yourselfbetter mantra borrowed from modern-day dating culture. The Sassy Gay Friend tells Ophelia "This is Hamlet we're talking about! There is something rotten in Denmark, and it's his piss-poor attitude!" (Gallivan, 2010) along with the exhortation to dump him. Levine might categorize it as a uniquely American cultural attitude towards Shakespeare that irreverently an enforced familiarity with a colonial canon as the point of departure.

The significance of this national penchant for parodying Shakespeare is clear: Shakespeare and his drama had become by the nineteenth century an integral part of American culture. It is difficult to take familiarities with that which is not already familiar; one cannot parody that which is not well known. (Levine, 36)

Familiarity is the first benchmark for parody, of course, but the subversiveness of laughter cannot be discounted. In the Sassy Gay Friend videos, we are not laughing with Shakespeare, but at him. Through the mobilization of a millennial form - the YouTube web series - the weight of tradition is dismissed as 'stupid' through association with narrative 'stupidity' of the tragic deaths of the heroines. Additionally, the narrative is refocused through the eyes of an effeminate gay man, a socially marginal presence. Parodies address themselves to the surface of Shakespeare's reputation; the text of his plays and poetry are only cues that set the scene and evoke a sense of a high-culture Shakespeare that is privileged and hence more gleefully bowdlerised. Laughter is not apolitical, but a function of destabilisation: the object of laughter is brought down, debased and its authority flouted.

When this laughter comes from the lesser end of a power equation, such as from subordinate classes, it erupts as the Bakhtinian 'carnivalesque', overturning hierarchies and subverting the norms of power. We find in the carnival the 'turnabout ...of continual shifting from top to bottom, from front to rear, of numerous parodies and travesties, humiliations, profanations, comic crownings and uncrownings.' (Bakhtin, 11) Like the Sassy Gay Friend videos that re-energise Shakespeare with the grafting of modern social justice and filmic tropes, the carnivalesque can bring a remote cultural icon closer with new frames of reference.

However, most popular media seeks to benefit from indirect reference to Shakespeare; from comparison or adaptation. This is what Lanier calls appropriation (2002), where 'Shakespeare is moved from one cultural or interpretative frame to another'. These products create a dialogue between the adjunct realms of Shakespeare and popular culture in order to market their content more effectively, and to associate new content with a signifier of quality. Lanier notes that a number of 'based upon' Shakespeare films that are essentially lighthearted and generic try to escape stereotyping through their association with literariness such as the film 10 Things I Hate About You (1999) based on The Taming of the Shrew, or Disney's Lion King (1994) that has obvious structural similarities with Hamlet.

With the porosity of the boundary between high and low culture, Shakespeare becomes an aesthetic touchstone (Lanier, 2002) that can shape consumers' 'aesthetic disposition' (Bourdieu, 1969). Lending 'cultural nobility' to products like Lion King, or the Star Trek film Star Trek VI: The 
Undiscovered Country (1991) extends both ways from object to subject. In modern capitalist society, products are consumed not only for their function, but also for status. PsuedoShakespearian pop culture enables their consumers to associate themselves with high culture, and simultaneously enables creators to reap the profits of popular media.

\section{Double-Access and Class Privilege}

A PhD at a rock concert, says Gripsrud, partakes in both sides of the cultural divide. (p. 199) They enjoy the offerings of low/popular culture, and can posit themselves as a classless, non-elitist subject without realising the inherent privileges of their position. Contrast this with a singleaccess audience that is unable to enjoy high culture due to lack of training; a layman at a classical violin recital can only respond to the surface impressions s/he receives but cannot participate in the discourse of classical music, musical pedigree or influence. S/he can listen, but cannot derive any pleasure, because of the layers of mediation that only those who are trained in elite cultural discourse can unpack.

"Taste classifies, and it classifies the classifier" (Bourdieu, 1979) is a statement that can serve as an entry point into the diverse stratifications and divisions of class and culture that form the quagmire of Shakespop. Who are these popular culture objects aimed at? Since what is popular is usually what produces the affect (ibid.) of identification, validation and representation, what is it that consumers are seeing affirmed in their own identity?

In this scenario, to insist that a high culture low/popular culture binary does not exist at all due to the easy reproducibility of objects (what Benjamin discusses in 'The Work of Art in an Age of Mechanical Reproduction', 1936) is a fallacy that deliberately obscures the privilege inherent in this transversal of high/low culture discourses. Increased access to books because of print capitalism is not the same as cultural or intellectual access. Poor, working-class audiences with little access to formal education and even lesser access to higher learning will be intellectually debarred from the metaphysical intricacies of Hamlet's soliloquy even if they read them independently. Their enjoyment of Sassy Gay Friend videos will be limited to the recognisable cinematic figure of the gay friend alone.

Cross-cultural hybrids like Sassy Gay Friend videos or Shakespearemints address themselves to a double-access audience only, and in that they are exclusionary. Those who are able to enjoy Star Trek VI and Kenneth Branagh's Hamlet (1996) because they recognise the original belong to this double-access category. Just like code-switching in linguistics, those with double access possess the vocabularies of both high culture and popular culture.

Educational institutions are deeply concerned with creating more individuals with double access. The urge to appropriate Shakespeare for popular uses is touted as a move towards 'repopularising' Shakespeare, often as a pedagogic tool in schools. "Comic book versions of Shakespeare are an underexplored resource for the teacher seeking to design imaginative exercises to engage the students' interest." says Marion D. Perret in 'Not Just Condensation: How Comic Books Interpret Shakespeare' (2004). She is speaking of Manga Shakespeare, a line of Japanese manga-style comics that make Shakespeare friendlier to schoolchildren. Manga Shakespeare retains the essence of the original; the format is changed to popular children's literature, but the intention is to pay homage to an aesthetic standard.

The primary task for the artist of a comic book version of Shakespeare is to convey as clearly as possible what the play says. The art work, ultimately, will be evaluated not just 
for itself but also in relation to the source it illustrates and illuminates... an obligation to present what Shakespeare's words say and imply. (Perret, 2004, p. 88)

Here too, we see consolidation rather than contestation over Shakespeare's authorial legacy. Class aspiration is written into the very form of these comics as they are aimed to encourage a deeper study of the originals. Despite the superficially generic and popular incarnation, Manga Shakespeare retains some ontological 'high culture' values and bears the weight of young students' desire to evolve into people with taste and distinction.

Selective hybridity is a hallmark of several Shakespop objects, such as Neil Gaiman's Sandman comics or stylised collectible kitsch products like Shakespeare bobbleheads. As briefly discussed before, these products make statements about those who consume them. The Tempest (1995-6) and Dream (1989) by Neil Gaiman, both issues that feature Shakespeare as a recurring character, rely heavily upon the reader's identification with discursive myths about Shakespeare as well as metatextual and intertextual references.
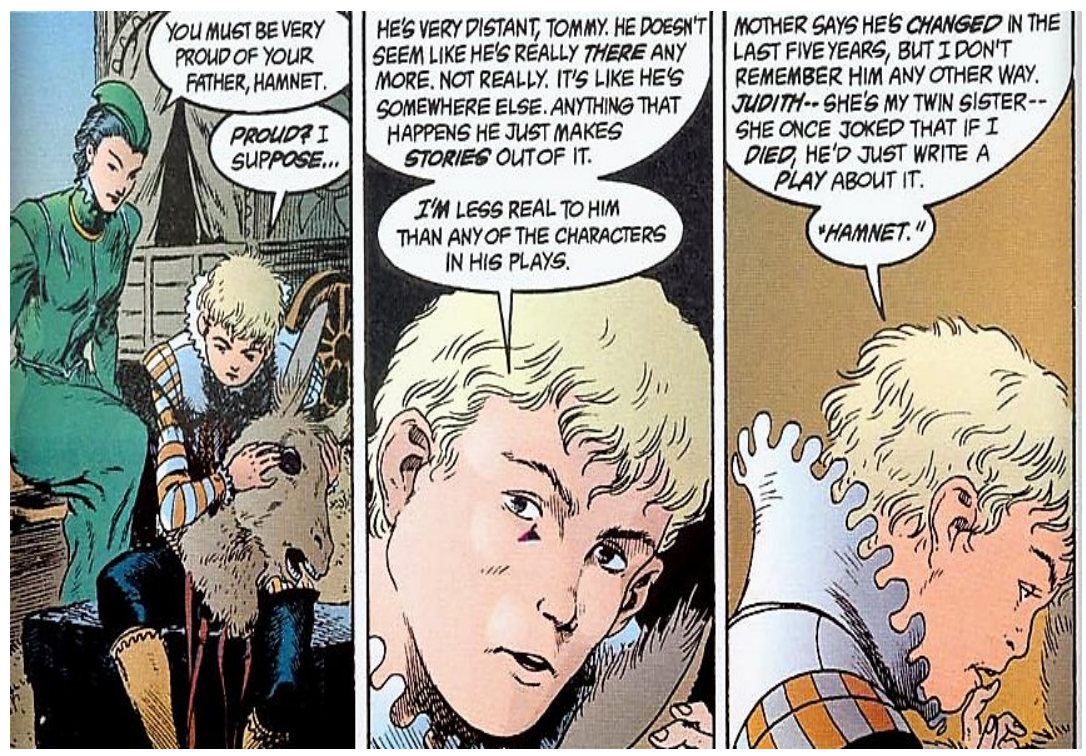

Figure 3. Hamnet in Sandman \#13, p. 14.

The pleasure of paratextual referentiality is only available to those who have access to higher education. The pun upon Hamlet/Hamnet works if one if aware of some of the critical debates (Greenblatt, 2004) surrounding the connection between the two. The character of Judith in Tempest (Gaiman, 1996) is drawn from biographical sources, for she was indeed Shakepeare's daughter. Her marginality in the narrative resonates with another critical work - Virginia Woolfs essay 'Shakespeare's Sister' in A Room of One's Own where she hypothesises the oppression that Shakespeare's genius would have endured were it birthed into a female body, a fictional sister named Judith. Annalisa Castaldo approaches Gaiman as a contributor to Shakespeare's biographical myth, a discourse immediately recognisable to Shakespeare scholars but not the average comic book reader.

Gaiman also makes a huge number of historical and literary references to, among others, Greek, Egyptian, and Norse myth, the Bible, Milton, A Thousand and One Arabian Nights and, of course, Shakespeare. ...Shakespeare as a character and a cultural symbol (emphasis mine) carries a significant part of the burden of the series' meditation on the character and meaning of dreams. (99) 
The form is ostensibly popular, but its function is to reinforce the status of both Gaiman as a 'serious' writer as well as its discerning reader. The category of 'discerning consumer of popular culture' is growing side-by-side with double access; as it becomes more respectable to dabble in populist forms of entertainment, consumers attempt to retain their class privilege by selecting those products that maintain a link with high cultural capital.

I borrow this analysis from Lanier (2007) who identifies the class anxiety at the root of such production. When 'Bardolatry' is no longer a fashionable position, mocking Shakespeare's iconic status becomes a privilege accorded to those who keep themselves equidistant from a high cultural register as well as mass capitalist consumerism. (95-97) It is simply double-access in action, now codified as a set of practices that can avoid crises of identity (between highbrow/lowbrow) and instead affirm this flexibility as a new virtue.

The result is a form of reciprocal irony: by attaching the Shakespeare trademark to an inappropriately pop object, the act of engaging in pop consumerism by buying or collecting it becomes self-consciously ironic ...any residual hint of snobbery involved in the invocation of Shakespeare becomes self-protectively parodic. In this context, the Shakespeare trademark marks the distinction between the run-of-the-mill consumer, simply immersed in pop media stream, and the connoisseur, conversant with two cultural registers at once (ibid, 97)

What we are witnessing here is social mobility inscribed in the very products that we buy. No longer are objects of pop culture capable of producing only one meaning, but several at the same time, thus creating in their use the external embodiment of privilege. The postmodern trap of believing that the distinction between high and low culture has disappeared is coterminous with believing that class distinctions have disappeared as well. Gripsrud warns against this tendency in researchers who, by not recognising their own class position, effectively conceal its origins.

The double access to the codes and practices of both high and low culture is a class privilege. Consequently, denial of the existence of significant differences between high and low culture is ideological in the most simplistic Marxist sense - it engenders ideas serving to conceal inequality in the distribution of power and other resources. Just like the traditional bourgeois wanted (wants!) us to believe that 'money means nothing, we're all equal', certain theorists of culture now want us to believe that 'knowing Aristotle, Shakespeare, Marx, Foucault and Godard means nothing, we're all equal'. (ibid, 199)

This crisis is one of class identity, says Jostein Gripsrud, as more ranks of university educated scholars come from more diverse class background, and find that they enjoy both high and mass culture products. Instead of a postmodernist lack of centricity or emptiness of meaning, which supposedly frees up this icon for joyful, carnivalesque use, Shakespeare is so overdetermined by layers of mediation and appropriation that it is impossible to restore him to a pure state. Instead, the stratification between the presumably discrete realms of highbrow/lowbrow culture and the 'residual usefulness of connotations of exclusivity, learnedness and quality' (Lanier, ibid) continue to act as driving forces behind the interaction of Shakespeare with pop culture.

It appears that Shakespeare cannot be returned to the groundlings, not only because there is nothing to return to, but also because the postmodern class divisions are so complex, that gatekeeping mechanisms prevent un-specialised or uneducated consumers from deriving pleasure from his work. If ever there was an organic connection between the masses and Shakespeare, the 
intervening centuries of institutionalization, colonization and mediation have alienated him from all those classes not endowed with the privilege of double-access. The fact that such attempts are constantly made, however, is testament to Shakespeare's continuing relevance and cultural power in contemporary times.

\section{References}

Abele, E. (2004). Introduction: Whither Shakespop? Taking stock of Shakespeare in popular culture. College Literature, 31(4), 1-11. Available at http://www.jstor.org/stable/25115224

Bakhtin, M. (1984). Introduction. Rabelais and his world. (H. Iswolsky, Trans.). pp. 1-58. Bloomington: Indiana University Press.

Benjamin, W. (1969). The work of art in the age of mechanical reproduction. In. H. Arendt (Ed.). \& H. Zohn (Trans). Illuminations. pp. 219-226. Retrieved from http://www.berkedu.com/VisualStudies/readingList/o6b_benjaminwork\%20of\%2oart\%2oin\%2othe\%2oage\%20of\%2omechanical\%2oreproduction.pdf.

Bourdieu, P. (1996). Distinction: A social critique of the judgement of taste. (R. Nice, Trans.). Cambridge Massachusetts: Harvard University Press.

Docx, E. (2016 Nov19). Leonard Cohen is John Donne to Bob Dylan's Shakespeare. The Guardian. Retrieved from https://www.theguardian.com/music/2016/nov/19/leonard-cohen-music-recalls-john-donnepoetry.

Dollimore, J., \& Sinfield, A. (Eds.) (1985). Introduction. Political Shakespeare: essays in cultural materialism (pp 8-15). New York: Cornell University Press.

Foucault, M. (1969). What is an author? In J.D. Faubion (Ed.). \& J. V. Harari (Trans.), The essential works of Foucault 1954-1984: Aesthetics, methods and epistemology Vol ii. pp. 205-222. Retrieved from http://web-facstaff.sas.upenn.edu/ cavitch/pdf-library/Foucault_Author.pdf.

Gaiman, N., \& Shakespeare, W. (1990). A midsummer night's dream. In (K. Berger, Ed.). The sandman: the dream country. 10.19. New York: DC Comics.

Gaiman, N., \& Shakespeare, W. (1996). The tempest. In (K. Berger, Ed.) The Sandman: The wake 10.75. New York: DC Comics.

Gallivan, B. [The Second City]. (2010, Feb 17). Sassy gay friend - Hamlet. [Video file] Retrieved from https://www.youtube.com/watch?v=jnvgq8STMGM.

Grande, T. (2009, May). Manga Shakespeare and the hermeneutic problems of 'double access'. Paper presented at Queen City comics conference. Retrieved from http://ourspace.uregina.ca/bitstream/handle/10294/3091/QueenCityComics-3Troni_Grande.pdf?sequence $=1 \&$ isAllowed $=\mathrm{y}$.

Greenblatt, S. (2004 Oct 21) The death of Hamnet and the making of Hamlet. The New York Review of Books. Retrieved from http://www.nybooks.com/articles/2004/10/21/the-death-of-hamnet-and-themaking-of-hamlet/.

Gripsrud, J. (2015). High culture revisited. Cultural Studies 3.2. pp. 194-207.

Lanier, D. (2002). Introduction: where no bard has gone before'. In D. Lanier (Ed.). Shakespeare and modern popular culture (pp. 1-20). Oxford: Oxford University Press.

Lanier, D. (2007) Shakespeare ${ }^{\mathrm{TM}}$ : myth and biographical fiction'. In R. Shaughnessy (Ed.) The Cambridge companion to Shakespeare and popular culture (pp.93-112). Cambridge: Cambridge University Press. 
Levine, L. W. (1984). William Shakespeare and the American people: A study in cultural transformation". The American historical review 89(1), 34-66. Available at http://www.jstor.org/stable/1855917.

Perret, M. D. (2004). Not just condensation: How comic books interpret Shakespeare. College Literature, 31(4), 12-18. Available at http://www.jstor.org/stable/25115224.

Plasse, M. A. (2004). Crossover dreams: reflections on Shakespeareans and popular culture'. College Literature, 31(4), 72-93. Available at http://www.jstor.org/stable/25115224.

The Unemployed Philosophers Guild. (2015). Shakespearemints. Retrieved from http://www.philosophersguild.com/Shakespearmints.html.

TV Tropes. (n.d) Gay best friend. (n.pub.). Retrieved from http://tvtropes.org/pmwiki/pmwiki.php/Main/GayBestFriend.

\section{Appendix 1}

Figure 1. "Shakespearemints' sold on The Unemployed Philosophers Guild; priced \$3”. TV Tropes. (n.d) Gay best friend. (n.pub.). Retrieved from http://tvtropes.org/pmwiki/pmwiki.php/Main/GayBestFriend.

Figure 2. "Brian Gallivan in 'Sassy Gay Friend - Hamlet”. Gallivan, B. [The Second City]. (2010, Feb 17). Sassy gay friend - Hamlet. [Video file] Retrieved from https://www.youtube.com/watch?v=jnvgq8STMGM.

Figure 3. "Hamnet in Sandman \#13, p. 14." Gaiman, N., \& Shakespeare, W. (1990). A midsummer night's dream. In (K. Berger, Ed.). The sandman: the dream country. 10.19. New York: DC Comics.

Laboni Bhattacharya teaches English at Hindu College, University of Delhi. She has completed her M.Phil in English from the University of Delhi, and her Masters and Bachelors in English from St. Stephens College and Hindu College respectively. Her areas of interest include fan studies and popular media as well as the use of social media in protest. ORCID id orcid.org/oooo-0oo2-97583235 Email: laboni.bhattacharya@gmail.com 